\title{
Effect of Dopant Concentration on the Structural, Optical and Sensing Properties of $\left(\mathrm{SnO}_{2}\right)_{1-\mathrm{x}}\left(\mathrm{TiO}_{2}: \mathrm{CuO}\right)_{\mathrm{x}}$ Sprayed Films
}

\author{
Sara S. Mahmood ${ }^{1^{*}}$ \\ Bushra A. Hasan ${ }^{2}$
}

Received 24/6/2018, Accepted 16/1/2019, Published 2/6/2019

This work is licensed under a Creative Commons Attribution 4.0 International License.

\begin{abstract}
:
Spray pyrolysis technique was subjected to synthesized $\left(\mathrm{SnO}_{2}\right)_{1-\mathrm{x}}\left(\mathrm{TiO}_{2}: \mathrm{CuO}\right)_{\mathrm{x}}$ Thin films on different substrates like glass and single crystal silicon using. The structure of the deposited films was studied using $\mathrm{x}$ ray diffraction. A more pronounced diffraction peaks of $\mathrm{SnO}_{2}$ while no peaks of $\left(\mathrm{CuO}, \mathrm{TiO}_{2}\right)$ phase appear in the X-ray profiles by increasing of the content of $\left(\mathrm{TiO}_{2}, \mathrm{CuO}\right)$ in the sprayed films. Mixing concentration $\left(\mathrm{TiO}_{2}, \mathrm{CuO}\right)$ influences on the size of the crystallites of the $\mathrm{SnO}_{2}$ films , the size of crystallites of the spray paralyzed oxide films change in regular manner by increasing of $\left(\mathrm{TiO}_{2}, \mathrm{CuO}\right)$ amount. The effect of mixing concentration on the optical properties of the films was also investigated. The reflectance and transmittance spectra in the wavelength range (300-1100) $\mathrm{nm}$ were employed to determine the optical properties such as energy band gap $(\mathrm{Eg})$ and refractive index $(\mathrm{n})$, extinction coefficient $(\mathrm{k})$, real and imaginary parts of dielectric constants $\left(\varepsilon_{1}, \varepsilon_{2}\right)$ for $\left(\mathrm{SnO}_{2}\right)_{1-\mathrm{x}}\left(\mathrm{TiO}_{2}: \mathrm{CuO}\right)_{\mathrm{x}}$ films. The energy band gap omit of which showed reduction from (3.65 to 2.2) eV by reducing of $\mathrm{SnO}_{2}$ amount from (100 to 70) \% .The reduction of energy band gap was ascribed to the new tail states introduced in the band gap of tin oxide. The sensitivity of the prepared sensor film was determined resistance difference of the films when exposed to oxidizing gas. The data declared that the mixed $\mathrm{SnO}_{2}$ films have better sensitivity in comparison with unmixed films.
\end{abstract}

Key words: Gas Sensors, Oxidation Gases $\mathrm{NO}_{3}, \mathrm{SnO}_{2}$ Thin Films, Spray Pyrolysis

\section{Introduction:}

It is well known that gas sensor can be fabricated from metal oxide like $\mathrm{SnO}_{2}, \mathrm{TiO}_{2}, \mathrm{Al}_{2} \mathrm{O}_{3}$, $\mathrm{CuO}, \mathrm{Fe}_{2} \mathrm{O}_{3}, \mathrm{WO}_{3}$, and $\mathrm{V}_{2} \mathrm{O}_{5}$ posses properties which can be changed with exposure to different gases. The concentration of gas can be detected is done by changing the sensor resistance, or by changing of the output voltage by applying a temperature gradient. $\mathrm{SnO}_{2}$ has unique properties it posses a low electrical resistance with high optical transparency in the visible range as well as suitable physicochemical properties and lower cost compared to actual available materials for the similar applications. It is sensitive to various oxidized and reduces gases such as vapors، ethanol, $\mathrm{H}_{2}, \mathrm{O}_{2}, \mathrm{CO}, \mathrm{NO}, \mathrm{NO}_{2}$ and $\mathrm{NH}_{3}$ at moderate operating temperature because gas sensing procedures strongly rely on the surface chemical reactions. On the other hand the natural nonstoichiometry and easy adsorption of oxygen of $\mathrm{SnO}_{2}$ lead to have a high reactivity to reduce gases at relatively low operating temperatures $(1,2)$.

\footnotetext{
${ }^{1}$ Ministry of Science and Technology

${ }^{2}$ Department of Physics, College of Science, University of Baghdad, Baghdad, Iraq.

*Corresponding author: sarasadiqphd@gmail.com
}

tin oxide considers as a wide band gap semiconductor $3.6 \mathrm{eV}$, where there is only one tin atom occupies the center of a surrounding core composed of six oxygen atoms placed approximately at the corners of a quasi-regular octahedron, while the oxygen atoms, there are three tin atoms surround each of them, forming an almost equilateral triangle. The lattice parameters are $a=b$ $=4.737 \mathrm{~A}^{\circ}$ and $c=3.186 \mathrm{~A}^{\circ}$. Due to these properties $\mathrm{SnO}_{2}$ is being introduced in many applications, such as electrode materials in solar cells, light-emitting diodes, flat-panel displays, and other optoelectronic devices. $\mathrm{SnO}_{2}$ thin films may be prepared by many techniques such as, sputtering, and pulsed laser deposition, spray pyrolysis, sol-gel process, chemical vapor deposition $(3,4)$.

Copper oxide (CuO, tenorite) (I-VI compound) considered as very interesting material, may appear in two phases which is cupric oxide or copper (II) oxide $(\mathrm{CuO})$; and cuprous oxide $\left(\mathrm{Cu}_{2} \mathrm{O}\right)$. In addition, $\mathrm{CuO}$ has band gap of $1.5-1.8 \mathrm{eV}$ a good electrical properties as well as inexpensive material, nontoxic nature. $\mathrm{CuO}$ thin film can be used as gas sensor for reducing gases and oxidizing gases. $\mathrm{CuO}$ possess positive conductance since holes are the majority carrier which has negative influence on the 
performance of the gas sensor. Thus $\mathrm{CuO}$ can be used to improve the gas sensor response of n-type oxides such as $\mathrm{ZnO}, \mathrm{WO}_{3}$, and $\mathrm{SnO}_{2}(1,5)$.

Titanium oxide $\mathrm{TiO}_{2}$ (IV-VI compound) can exist in three forms which are anatase, rutile and brookite which influences the sensing properties. The anatase phase is most suitable in gas sensing due to its higher photo catalytic activity while the other phases Anatase and brookite are thermodynamically metastable which convert to rutile at high temperatures. Titanium dioxide $\left(\mathrm{TiO}_{2}\right)$ is preferred in the fabrication of gas sensors due to its nontoxic nature, chemical stability, and commercial availability at a low cost, robust, and general reactivity. Titanium dioxide can be prepared by different methods such as chemical bath deposition, spray pyrolysis sol-gel method and chemical vapor deposition (6) Spray pyrolysis technique among these methods, has got many advantages such as the lower cost, accurate control over the deposition parameters and, high growth rate and mass production capability for uniform large area films deposition (7).

The sensitivity $(\mathrm{S})$ is defined as $\mathrm{S}=(\mathrm{Ra}-$ $\mathrm{Rg}) / \mathrm{Rg}$, where $\mathrm{Rg}$ is the resistance in presence of test gas and $\mathrm{Ra}$ the film resistance in ambient air, measured at respective temperatures. A positive value of $\mathrm{S}$ implies film resistance decreases on gas exposure and vice versa $(8,9)$.

The aim of this work was to considerably improve the gas sensing properties of $\mathrm{SnO}_{2}$-based sensors by mixed with metal oxides $\left(\mathrm{TiO}_{2}, \mathrm{CuO}\right)$ and investigate the effect on (of) doping on the structural and optical properties.

\section{Materials and Methods}

The films were deposited on the glass and Silicon wafer which were subjected previously to many stages for cleaning to remove and dusts grease and other impurity at a temperature of $523 \mathrm{~K}$ by spray pyrolysis technique (CSP).Spray pyrolysis equipment consists of an atomizer, precursor solution, substrate heater, and temperature controller as shown in Fig.1.

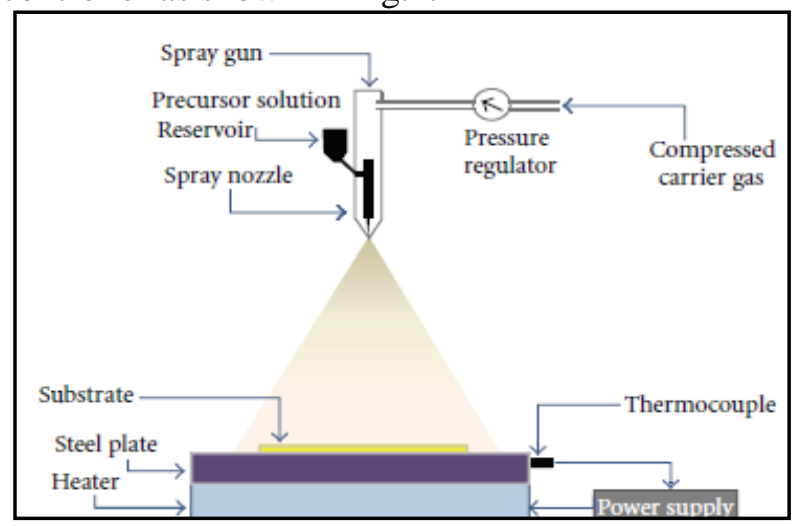

Figure 1. The scheme of the spray pyrolysis setup. (8)
Thin-film deposition, using solution of a metal salt ,To prepare metal oxide semiconductor material $\mathrm{SnO}_{2}, \mathrm{TiO}_{2}$ and $\mathrm{CuO}$ using an aqueous solution of dehydrate Tin chloride $\left(\mathrm{SnCl}_{2} \cdot 2 \mathrm{H}_{2} \mathrm{O}\right)$, dehydrate Copper chloride $\left(\mathrm{CuCl}_{2} \cdot 2 \mathrm{H}_{2} \mathrm{O}\right)$ and $\mathrm{TiCl}_{3}(0.2 \mathrm{M})$ this material was dissolved to obtain clearly solution with total volume of $(50 \mathrm{ml})$, with $(5 \mathrm{Sec})$ of spray time and constant spray interval $(55 \mathrm{sec})$ to avoid excessive cooling, the carrier gas (filtered compressed air)was maintained at a pressure of $10^{5} \mathrm{Nm}^{-2}$, distance between nozzle and the substrate was about $25 \mathrm{~cm}$.

The thicknesses ( $\mathrm{t}$ ) can be determined using Optical Interference Fringe method was calculated by using equation (10)

$t=\frac{\Delta x}{x} \times \frac{\lambda}{2}$

$\Delta \mathrm{x}$ : The displacement of the fringe across the film substrate step, $x$ : is the fringe spacing. The structure of prepared thin films was checked by Xray diffraction (XRD), (Miniflex Model) using $\mathrm{CuK} \alpha$ radiation with a wavelength $\lambda=1.5418 \AA$ at $2 \theta$ values between $\left(20^{\circ}-80^{\circ}\right)$.

The crystallite size (D) was calculated using the Scherrer equation as follows:

$D=0.9 \lambda / \beta \cos \theta \ldots \ldots \ldots \ldots . .2$

Where $\lambda$ is the $\mathrm{X}$-ray wavelength, $\beta$ is the full width at half maximum of the diffraction peak and Bragg's diffraction angle. The lattice constants $(a, b$, and $c)$ for of crystal (thin films) can be determined by the equation for tetragonal (11)

$\frac{1}{d^{2}}=\frac{\left(h^{2}+k^{2}\right)}{a^{2}}+\frac{l^{2}}{c^{2}} \quad \ldots \ldots \ldots \ldots . . .3$

where (d) and (hkl) the inter planar distance and Miller indices, respectively.

\section{Optical Properties:}

Optical transmittance and absorbance were recorded in the wavelength range (300-1100) $\mathrm{nm}$ using UV-VIS spectrophotometer at room temperature. In the fundamental absorption region the transmission $\mathrm{T}$ is given by:

$T=A \exp \left(-\frac{4 \pi k t}{\lambda}\right) \quad \ldots \ldots \ldots \ldots . . .4$

where $\mathrm{A}$ is a constant and $\mathrm{k}$ is the extinction coefficient. The absorption coefficient $(\alpha)$ could be calculated using the following relation (12):

$\alpha=\frac{2.303 A}{t} \quad \ldots \ldots \ldots \ldots . .5$

where (A) is the absorption, optical band gap calculated from equation which is known as (Tauc) relation is:

$\alpha h v=B\left(h v-E_{o p t}\right)^{r} \ldots \ldots \ldots \ldots \ldots 6$

where (hv) is the energy of absorbed light, $\mathrm{n}$ is the parameter connected with distribution of the density of states and B, a constant or (Tauc) parameter, here $r=1 / 2$ for direct and $r=2$ for indirect transitions. In 
order to calculate the optical constant refractive index (n) and the extinction coefficient $(\mathrm{k})$ of the films at different wavelengths, we can use the following relations: (13)

$$
\begin{aligned}
& R=\frac{(n-1)^{2}+k^{2}}{(n+1)^{2}+k^{2}} \ldots \ldots \ldots \ldots \ldots . . .7 \\
& k=\frac{\alpha \lambda}{4 \pi} \ldots \ldots \ldots \ldots \ldots \ldots . . . .
\end{aligned}
$$

The obtained values of $\mathrm{n}$ and $\mathrm{k}$ were used to calculate both $\left(\varepsilon_{r}\right)$ and imaginary $\left(\varepsilon_{\mathrm{i}}\right)$ parts of the dielectric constant and they were obtained using the formulas:

$\varepsilon_{\mathrm{r}}=\mathrm{n}^{2}-\mathrm{k}^{2}$

$\varepsilon_{\mathrm{i}}=2 \mathrm{nk}$

where $\varepsilon_{r}$ determines the maximum energy that can be stored in the material, $\varepsilon_{i}$ also is called the relative loss factor and represents the absorption of electrical energy by a dielectric material that is subjected to an alternating electromagnetic field.

\section{Results and Discussion: \\ Structural Properties}

The $\mathrm{X}$ ray diffraction spectra of $\left(\mathrm{SnO}_{2}\right)_{1-x}$ $\left(\mathrm{TiO}_{2}: \mathrm{CuO}\right)_{\mathrm{x}}$ thin films prepared at $523 \mathrm{~K}$ with different mixing concentration are shown in Fig.2.

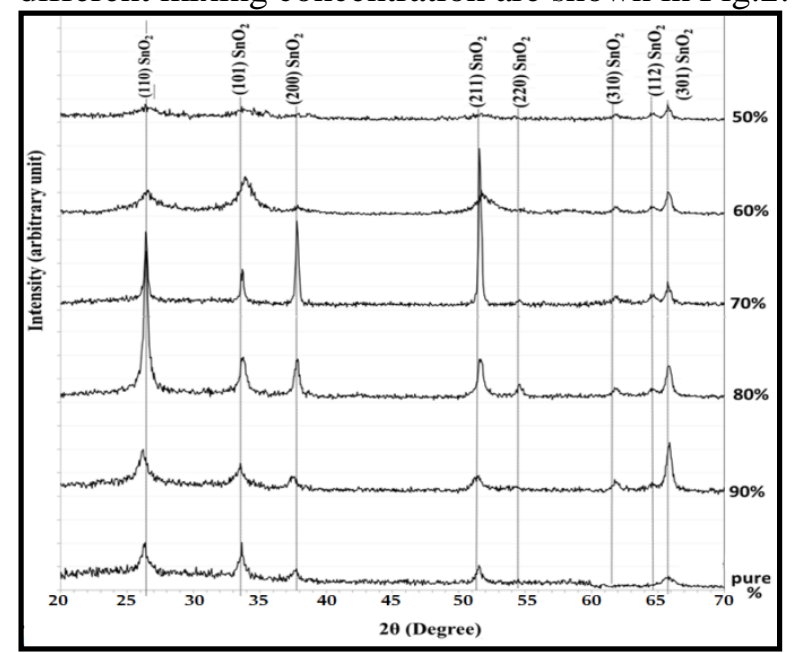

Figure 2. X-ray Diffraction Patterns of Deposited $\left(\mathrm{SnO}_{2}\right)_{1-x}\left(\mathrm{TiO}_{2}: \mathrm{CuO}\right)_{x}$ Thin Films

In Table1 it can be noticed the structural parameters: Angle of diffraction $(2 \theta)$, the distance between crystal planes $\left(\mathrm{d}_{\mathrm{hkl}}\right)$, Miller indices (hkl), the Full-Width Half Maximum (FWHM ) and crystal size (C.S) of films.

\begin{tabular}{|c|c|c|c|c|c|c|}
\hline $\mathrm{SnO}_{2} \%$ & $2 \theta$ (Deg.) & FWHM(Deg.) & $\mathrm{d}_{\mathrm{hk}}$ Exp. $(\AA)$ & C.S (nm) & hkl & $\mathrm{d}_{\mathrm{hkl}} \operatorname{Std} .(\AA)$ \\
\hline & 26.3543 & 0.8344 & 3.3791 & 9.8 & (110) & 3.3498 \\
\hline & 33.6714 & 0.7702 & 2.6596 & 10.8 & (101) & 2.6439 \\
\hline \multirow[t]{3}{*}{ Pure } & 37.6508 & 0.6418 & 2.3872 & 13.1 & (200) & 2.3686 \\
\hline & 51.5148 & 0.8344 & 1.7726 & 10.6 & (211) & 1.7642 \\
\hline & 65.7638 & 1.2195 & 1.4188 & 7.8 & (301) & 1.4149 \\
\hline \multirow[t]{5}{*}{$90 \%$} & 51.4506 & 0.8344 & 1.7747 & 10.6 & (211) & 1.7642 \\
\hline & 65.8922 & 0.5135 & 1.4164 & 18.4 & (301) & 1.4149 \\
\hline & 26.4185 & 0.4493 & 3.3710 & 18.2 & (110) & 3.3498 \\
\hline & 33.7356 & 0.6419 & 2.6547 & 12.9 & (101) & 2.6439 \\
\hline & 37.8434 & 0.5134 & 2.3754 & 16.4 & (200) & 2.3686 \\
\hline \multirow[t]{5}{*}{$80 \%$} & 51.6431 & 0.4493 & 1.7685 & 19.7 & (211) & 1.7642 \\
\hline & 65.8280 & 0.7060 & 1.4176 & 13.4 & (301) & 1.4149 \\
\hline & 26.4185 & 0.3209 & 3.3710 & 25.4 & (110) & 3.3498 \\
\hline & 33.6714 & 0.3851 & 2.6596 & 21.6 & (101) & 2.6439 \\
\hline & 37.7792 & 0.3210 & 2.3793 & 26.2 & (200) & 2.3686 \\
\hline \multirow[t]{5}{*}{$70 \%$} & 51.5789 & 0.3209 & 1.7705 & 27.5 & (211) & 1.7642 \\
\hline & 65.6996 & 0.5135 & 1.4201 & 18.4 & (301) & 1.4149 \\
\hline & 26.6110 & 1.3479 & 3.3470 & 6.1 & (110) & 3.3498 \\
\hline & 33.9281 & 1.0912 & 2.6401 & 7.6 & (101) & 2.6439 \\
\hline & 37.8434 & 0.5776 & 2.3754 & 14.5 & (200) & 2.3686 \\
\hline \multirow[t]{5}{*}{$60 \%$} & 51.7073 & 1.1553 & 1.7664 & 7.6 & (211) & 1.7642 \\
\hline & 65.7638 & 0.6418 & 1.4188 & 14.7 & (301) & 1.4149 \\
\hline & 26.2901 & 1.2195 & 3.3872 & 6.7 & (110) & 3.3498 \\
\hline & 33.7356 & 1.0270 & 2.6547 & 8.1 & (101) & 2.6439 \\
\hline & 37.9718 & 1.1553 & 2.3677 & 7.3 & (200) & 2.3686 \\
\hline \multirow[t]{2}{*}{$50 \%$} & 51.5789 & 1.1553 & 1.7705 & 7.6 & (211) & 1.7642 \\
\hline & 65.7638 & 0.5776 & 1.4188 & 16.4 & (301) & 1.4149 \\
\hline
\end{tabular}

Table 1. XRD patterns of $\left(\mathrm{SnO}_{2}\right)_{1-\mathrm{x}}\left(\mathrm{TiO}_{2}: \mathrm{CuO}\right)_{\mathrm{x}}$ films with various mixing ratios.

The diffraction spectra reveals polycrystalline structure for all samples, and the peaks are indexed to JCPDS standard card No. 96210-4744 (14). The rutile type phase of $\mathrm{SnO}_{2}$ with a tetragonal unit cell showing a preferred orientation along (110) plane at $2 \theta=26.35^{\circ}$ that agree with (15). 
The peaks of the diffraction are increased by increasing the ratios at $(80$ and 70$) \%$, then decreasing at (60 and 50) \%. the appearance and disappearance of new peaks as a result of increasing the proportion of mixing and No traces of copper metal or titanium oxides could be detected within the detection limit of XRD, on the other hand there is a slight shift in the major peak of the structure may be attributed to the overlap of $\mathrm{TiO}_{2}$ and $\mathrm{SnO}_{2}$ peaks. Indeed the crystal size get to change reach maximum value $(25.4) \quad \mathrm{nm}$ at $70 \% \quad \mathrm{SnO}_{2}$ concentration which accompanied maximum absorbance as seen later (decreases, increases and return to decrease). Minimum vale $6.1 \mathrm{~nm}$ at $60 \%$ $\mathrm{SnO}_{2}$ creates favorable conditions for catalytic reactions giving rise to the large surface area and high number of active sites.

\section{Optical Properties}

The optical transmittance of $\left(\mathrm{SnO}_{2}\right)_{1-}$ ${ }_{x}\left(\mathrm{TiO}_{2}: \mathrm{CuO}\right)_{\mathrm{x}}$ thin films deposited by spray pyrolysis method measured in the wavelength range (3001100) $\mathrm{nm}$ plotted in Fig.3. At all $\left(\mathrm{SnO}_{2}\right)_{1-\mathrm{x}}$ $\left(\mathrm{TiO}_{2}: \mathrm{CuO}\right)_{\mathrm{x}}$ thin films the transmittance reduced by reducing of $\mathrm{SnO}_{2}$ concentration . Minimum transmittance (maximum absorption) occurs at $70 \%$ mixing ration corresponding to heist crystal size .This affirms the relation between structural enhancement and reduction of optical energy gap.

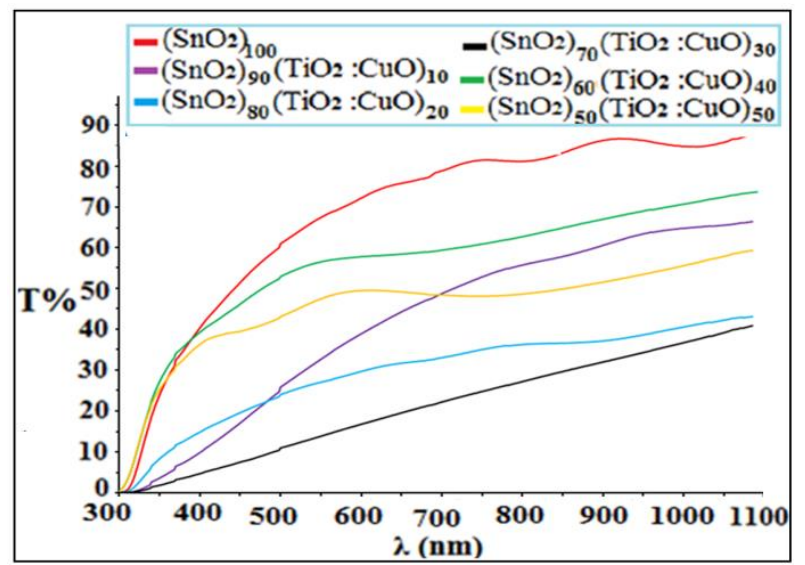

Figure 3. The transmittance as a function of wavelength of $\left(\mathrm{SnO}_{2}\right)_{1-x}\left(\mathrm{TiO}_{2}: \mathrm{CuO}\right)_{\mathrm{x}}$ films.

The optical band-gap values, $E_{\mathrm{opt}}$, were estimated according to (Tauc) formula was from the absorption coefficient spectra computed from the (Burguer- Lambert) equation. A typical energy gap were determiner in the highest absorption region were $\alpha>10^{4} \mathrm{~cm}^{-1}$ by plotting $(\alpha \mathrm{h} v){ }^{1 / \mathrm{r}}$ where $\mathrm{r}=0.5$ for direct allowed transition as in Fig.4. The optical energy gap values determined by fitting to $h v=0$. The optical energy gap has the same trend of optical transmittance i.e. Get to reduce by increasing of oxides concentration up $70 \%$ and return to increase for residual doping concentration. The reduction of energy gap related with increase of crystal size which responsible about the increase of absorption coefficient .On the other hand tail states established by adding oxides lead to visual decrease of energy gap, the continues of addition of dopant atoms leads to fill tail states and widen the band gap.

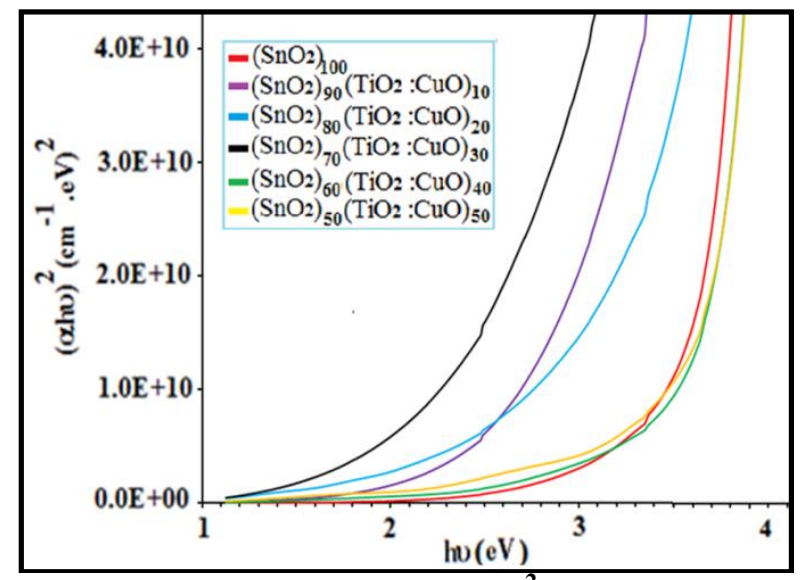

Figure 4. Variation of $(\alpha \mathrm{hv})^{2}$ versus photon energy (hv) of $\left(\mathrm{SnO}_{2}\right)_{1-\mathrm{x}}\left(\mathrm{TiO}_{2}: \mathrm{CuO}\right)_{\mathrm{x}}$ films.

The plot diagram of refractive index as (a) function of wavelength of $\left(\mathrm{SnO}_{2}\right)_{1-\mathrm{x}}\left(\mathrm{TiO}_{2}: \mathrm{CuO}\right)_{\mathrm{x}}$ thin films in the range (300-1100) $\mathrm{nm}$ is shown in Fig.5.It is evident that mixing ratio has valuable influence of the refractive index values .The refractive index increases with increasing of mixing ratio up $70 \%$ and then decreases. The values of refractive index are listed in Table 2.

The variation trend of extinction coefficient of with wavelength is shown in Fig.6. The behavior explanation of extinction coefficient is increase of absorption coming from addition of oxides reflect as increase of extinction coefficient, while the reduction of $\mathrm{k}$ coming from filling of tail states and hence reduction of absorption as shown in Table2. and Fig. 7, 8displays the behavior of the real $\left(\varepsilon_{1}\right)$ and imaginary $\left(\varepsilon_{\mathrm{i}}\right)$ parts of the dielectric constant values versus wavelength in the range $(300-1100) \mathrm{nm}$ for of $\left(\mathrm{SnO}_{2}\right)_{1-\mathrm{x}}\left(\mathrm{TiO}_{2}: \mathrm{CuO}\right)_{\mathrm{x}}$ thin films deposited at R.T with different concentrations. The variation trend of $\varepsilon_{\mathrm{r}}$ is similar to that of the refractive index because of the small value of $k^{2}$ compared with $\mathrm{n}^{2}$ according to equation 7 , while $\varepsilon_{2}$ is mainly depends on the $\mathrm{k}$ values. Thus similar explanation can be given to that of refractive index and extinction coefficient. 




Figure 5. Refractive index as a function of wavelength of $\left(\mathrm{SnO}_{2}\right)_{1-\mathrm{x}}\left(\mathrm{TiO}_{2}: \mathrm{CuO}\right)_{\mathrm{x}}$ thin films.

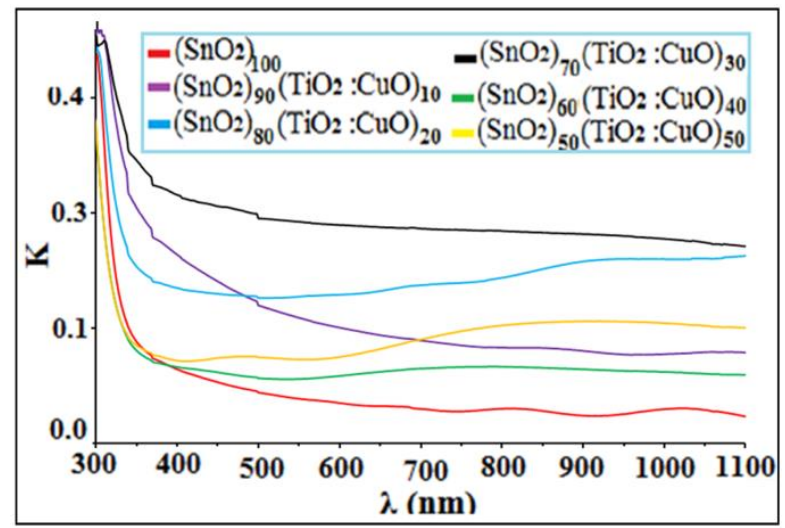

Figure 6. Extinction coefficient as a function of wavelength of $\left(\mathrm{SnO}_{2}\right)_{1-\mathrm{x}}\left(\mathrm{TiO}_{2}: \mathrm{CuO}\right)_{\mathrm{x}}$ thin films.

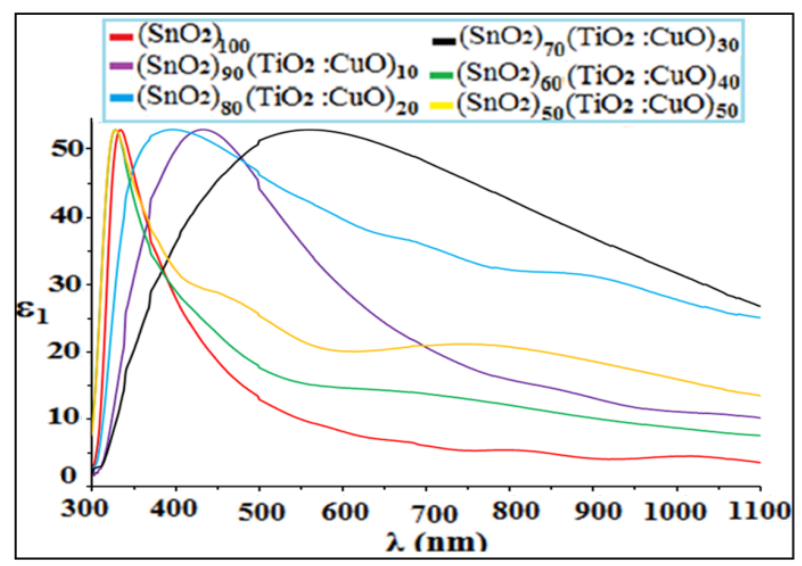

Figure 7. The real dielectric constant as a function of wavelength of $\left(\mathrm{SnO}_{2}\right)_{1-\mathrm{x}}\left(\mathrm{TiO}_{2}: \mathrm{CuO}\right)_{x}$ thin films.

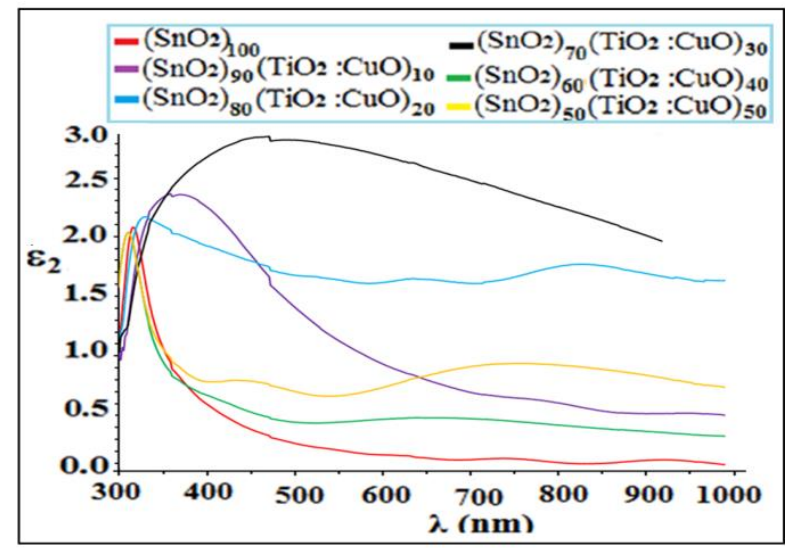

Figure 8. The imaginary dielectric constant as a function of wavelength of $\left(\mathrm{SnO}_{2}\right)_{1-\mathrm{x}}\left(\mathrm{TiO}_{2}: \mathrm{CuO}\right)_{\mathrm{x}}$ thin films

Table 2. Optical Energy Gap and Optical Constants at $\lambda=500 \mathrm{~nm}$ of $\left(\mathrm{SnO}_{2}\right)_{1-\mathrm{x}}\left(\mathrm{TiO}_{2}: \mathrm{CuO}\right)_{\mathrm{X}}$ Thin Films

\begin{tabular}{cccccccc}
\hline $\mathrm{SnO}_{2} \%$ & $\mathrm{~T} \%$ & $\alpha\left(\mathrm{cm}^{-1}\right)$ & $\mathrm{K}$ & $\mathrm{n}$ & $\varepsilon_{1}$ & $\varepsilon_{2}$ & $\mathrm{Eg}(\mathrm{eV})$ \\
\hline Pure & 78.6 & 5348 & 0.029 & 2.46 & 6.084 & 0.147 & 3.65 \\
90 & 48.7 & 16008 & 0.089 & 4.55 & 20.697 & 0.811 & 2.7 \\
80 & 33 & 24626 & 0.137 & 5.987 & 35.826 & 1.643 & 2.65 \\
70 & 22.2 & 33444 & 0.186 & 6.95 & 48.27 & 2.59 & 2.2 \\
60 & 59.3 & 11627 & 0.064 & 3.715 & 13.804 & 0.481 & 3.6 \\
50 & 48.3 & 16161 & 0.09 & 4.578 & 20.956 & 0.824 & 3.59 \\
\hline
\end{tabular}

Gas Sensors Measurements

A-Effect of operation temperature on the sensor:

Fig (9 13) displays the variation of resistance with time for $\left(\mathrm{SnO}_{2}\right)_{1-\mathrm{x}}\left(\mathrm{TiO}_{2}: \mathrm{CuO}\right)_{\mathrm{x}}$ thin films. to $\mathrm{NO}_{2}$ oxidizing gas at different operating temperature $(273,373,473$ and 573) and mixing ratio prepared at silicon with negative conductance. 


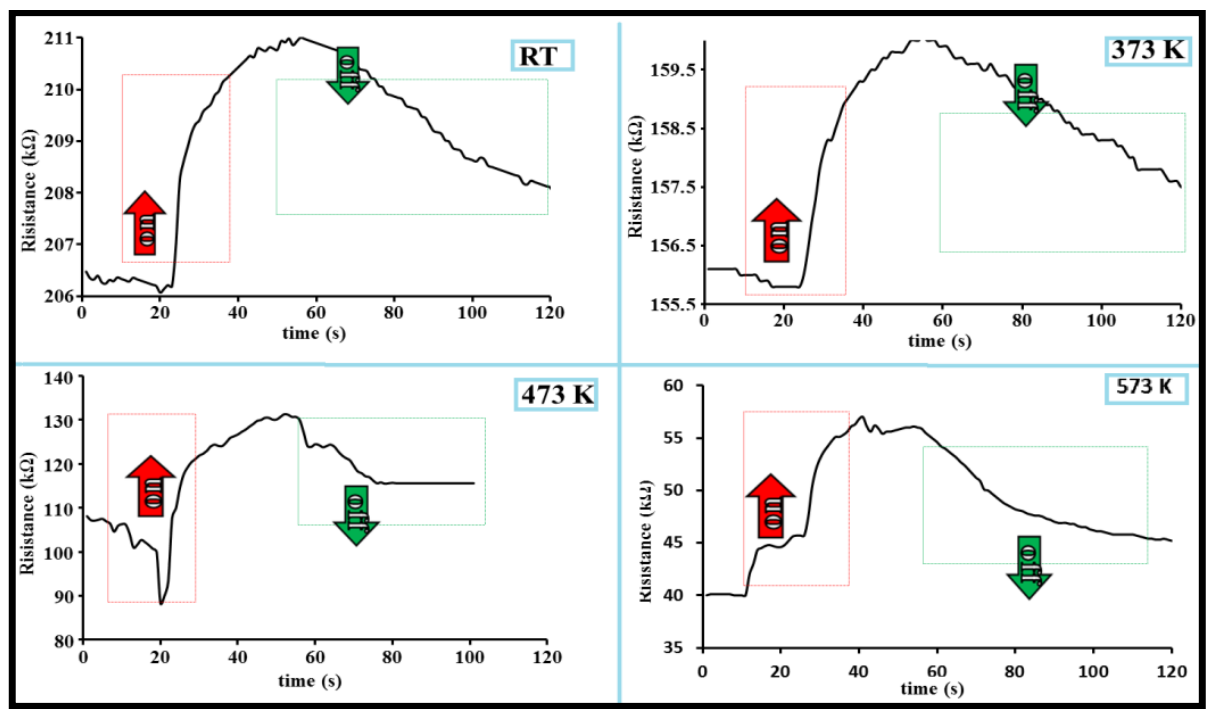

Figure 9. The resistance as a function of time for $\left(\mathrm{SnO}_{2}\right)$ at different temperatures.

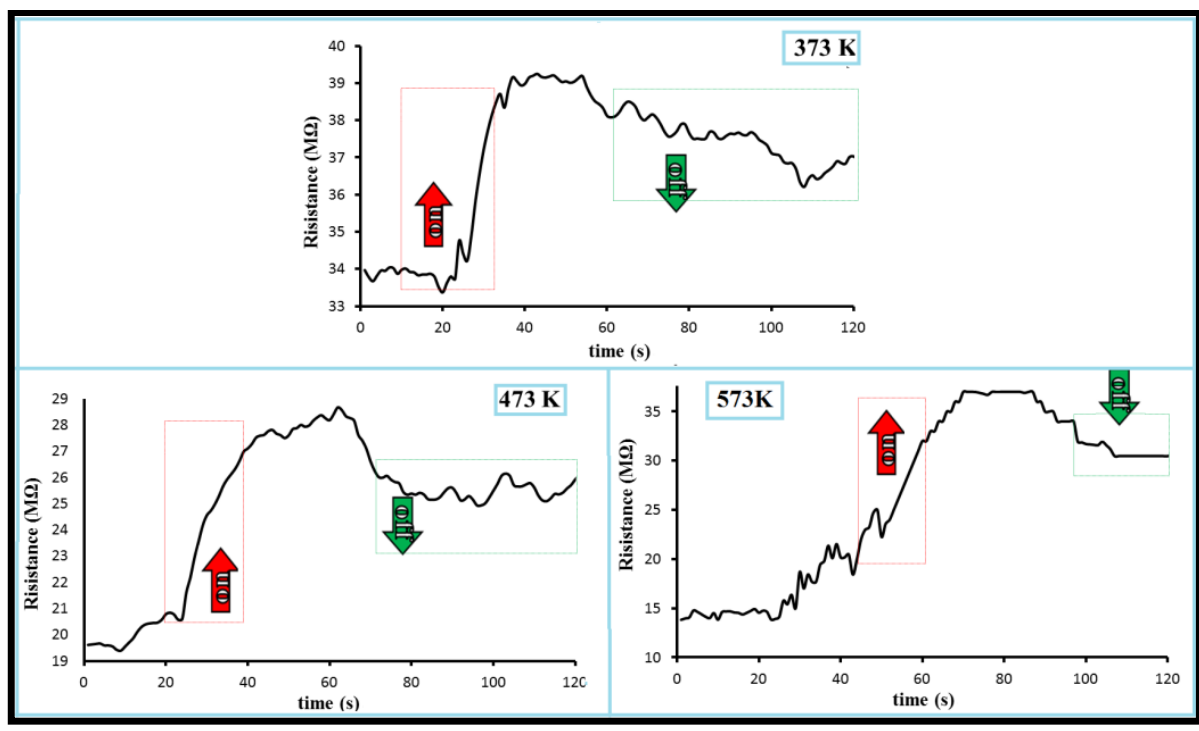

Figure 10. The resistance as a function of time for $\left(\mathrm{SnO}_{2}\right)_{90}\left(\mathrm{TiO}_{2}: \mathrm{CuO}\right)_{10}$ deposited on $\mathrm{n}-\mathrm{Si}$ at different temperatures.

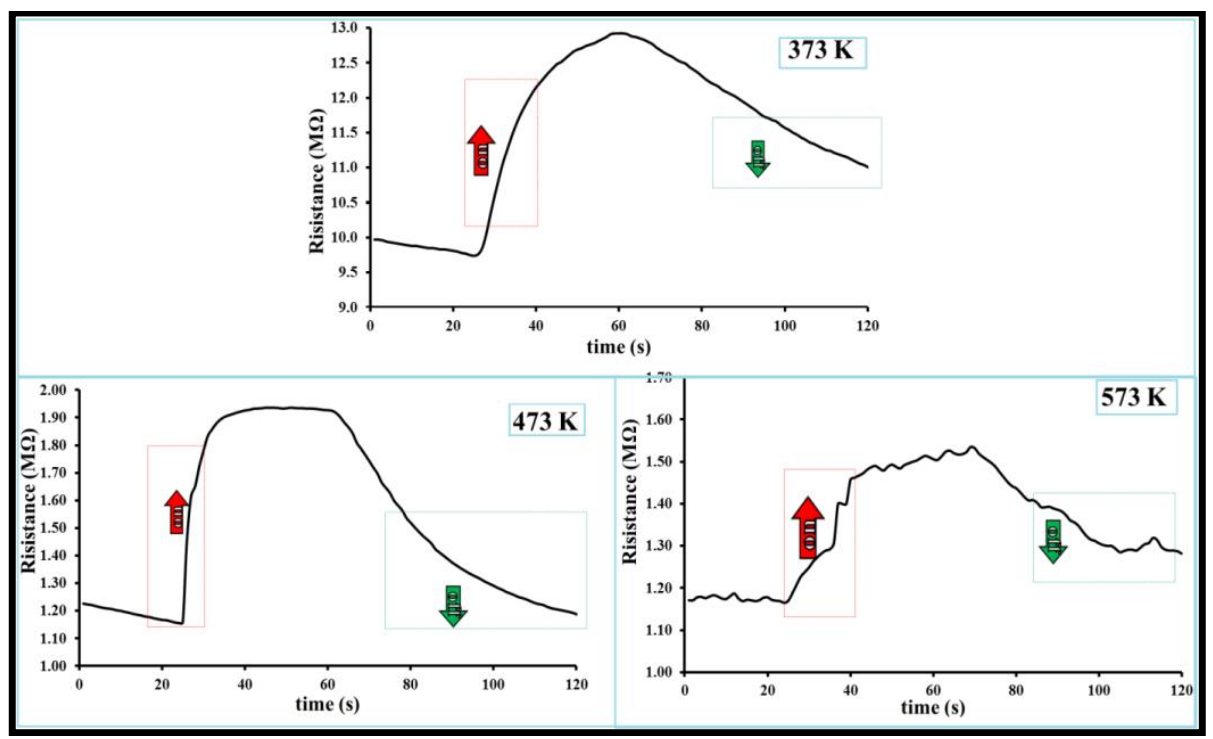

Figure 11. The resistance as a function of time for $\left(\mathrm{SnO}_{2}\right)_{80}\left(\mathrm{TiO}_{2}: \mathrm{CuO}\right)_{20}$ deposited on $\mathrm{n}$ - $\mathrm{Si}$ at different temperatures. 



Figure 12. The resistance as a function of time for $\left(\mathrm{SnO}_{2}\right)_{70}\left(\mathrm{TiO}_{2}: \mathrm{CuO}\right)_{30}$ at $(473 \mathrm{~K})$ and $\left(\mathrm{SnO}_{2}\right)_{50}\left(\mathrm{TiO}_{2}\right.$ : $\mathrm{CuO})_{50}$ at (573K).



Figure13. The resistance as a function of time for $\left(\mathrm{SnO}_{2}\right)_{60}\left(\mathrm{TiO}_{2}: \mathrm{CuO}\right)_{40}$ deposited on $\mathrm{n}$ - $\mathrm{Si}$ at different temperatures.

The results show that the sensitivity of the gas sensors increases with the increase of the operating temperature in the moderate range i.e. $473 \mathrm{~K}$ and then reduced at elevate temperature. While the sensitivity increases with increase of mixing ratio (reduction of $\mathrm{SnO}_{2}$ concentration). Hence maximum sensitivity $80 \%$ corresponds to crystal size $14.7 \mathrm{~nm}$ of the preferred orientation plane obtained for $60 \% \quad \mathrm{SnO}_{2}$ concentration at a temperature of $473 \mathrm{~K}$ which is called the optimal temperature as shown in Fig 14.

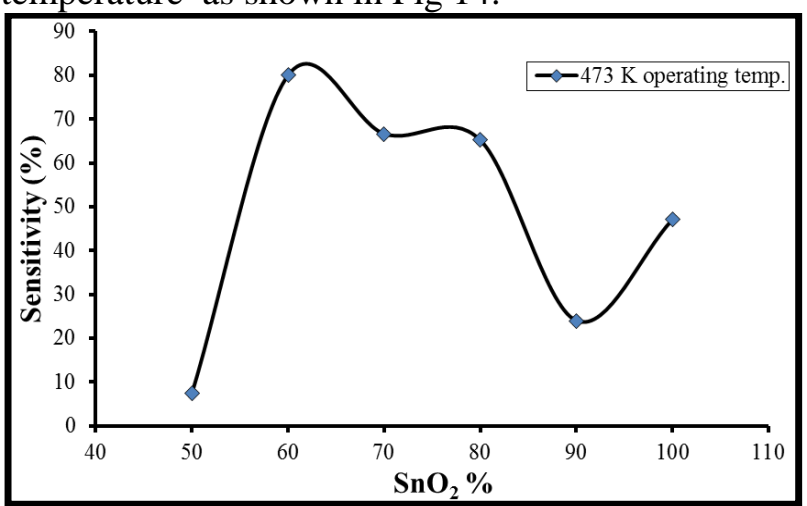

Figure 14. Sensitivity as function for $\left(\mathrm{SnO}_{2}\right)_{1}$ ${ }_{x}\left(\mathrm{TiO}_{2}: \mathrm{CuO}\right)_{\mathrm{x}}$ films at $473 \mathrm{~K}$.
The increase and decrease in the sensitivity indicates the adsorption and desorption phenomenon of the gas sensor. Mixing system has more oxygen is available for catalytic surface reactions and more free electrons return back into the bulk during those reactions .Enhanced catalytic activity together with amplified resistance changes due to charge transfer effects make sensors superior to single-oxide sensors. Note from the Table 3 that Sensitivity at the rate of $50 \% \mathrm{SnO}_{2}$ concentration server drastic reduction due to further increase of $\left(\mathrm{TiO}_{2}\right.$ and $\left.\mathrm{CuO}\right)$ content causes the decline of sensor performance, which is associated with agglomeration of particles into larger grains and reduction of their catalytic activity, that agree with $(16,17)$.

B- Response and Recovery Times:

The values of the response time and the recovery time for $\left(\mathrm{SnO}_{2}\right)_{1-\mathrm{x}}\left(\mathrm{TiO}_{2}: \mathrm{CuO}\right)_{\mathrm{x}}$ at operating temperatures $473 \mathrm{~K}$ shown in Fig. 15. The response time reduced and reach minimum value at $80 \%$ $\mathrm{SnO}_{2}$ concentration, also the recovery time vary with the increase of mixing ratio, however the 
recovery time reaches minimum value at $50 \% \mathrm{SnO}_{2}$ concentration (18).

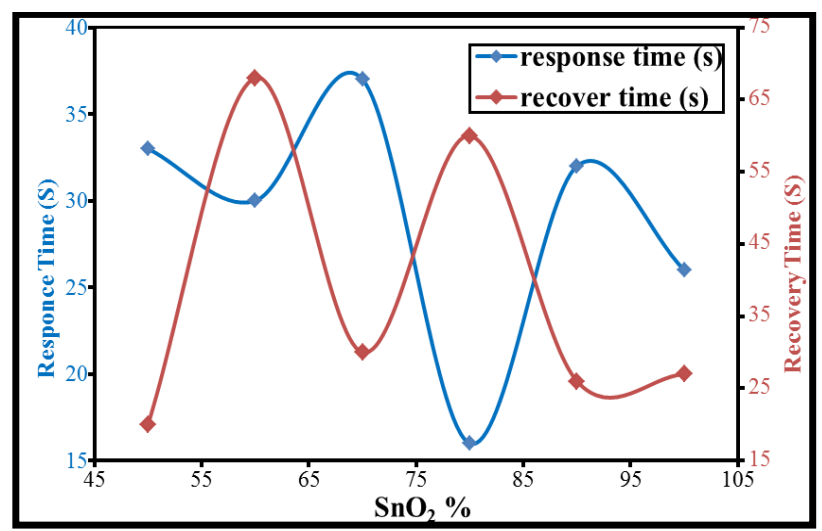

Figure 15. Response and recovery time of $\left(\mathrm{SnO}_{2}\right)_{1-\mathrm{x}}\left(\mathrm{TiO}_{2}: \mathrm{CuO}\right)_{\mathrm{x}}$ films at $473 \mathrm{~K}$

Table 3. Sensitivity, response and recovery function of operating temperature for $\left(\mathrm{SnO}_{2}\right)_{1-\mathrm{x}}$ $\left(\mathrm{TiO}_{2} \text { : } \mathrm{CuO}\right)_{x}$ films deposited on $\mathrm{n}-\mathrm{Si}$ at different temperatures to $\mathrm{NO}_{2}$ gas.

\begin{tabular}{ccccc}
\hline $\begin{array}{c}\text { SnO } \\
\mathbf{2} \%\end{array}$ & $\begin{array}{c}\text { temp. } \\
\text { (K) }\end{array}$ & $\begin{array}{c}\text { Sensitivit } \\
\mathbf{y}(\boldsymbol{\%})\end{array}$ & $\begin{array}{c}\text { Responseti } \\
\text { me (sec) }\end{array}$ & $\begin{array}{c}\text { recover } \\
\text { time (sec) }\end{array}$ \\
\hline 100 & R.T. & 2.43 & 33.00 & 82.00 \\
(Pur & 373 & 2.6 & 30.0 & 75.0 \\
e) & 473 & 47.1 & 26.0 & 27.0 \\
& 573 & 42.5 & 28.0 & 40.0 \\
90 & R.T. & - & - & - \\
& 373 & 15.9 & 28.8 & 86.4 \\
& 473 & 36 & 27 & 60.3 \\
& 573 & 123.9 & 36.9 & 61.2 \\
80 & R.T. & & & \\
& 373 & 32.7 & 32.0 & 75.0 \\
& 473 & 65.2 & 16.0 & 60.0 \\
70 & 573 & 25.0 & 33.0 & 63.0 \\
& R.T. & - & - & - \\
& 373 & - & - & - \\
& 473 & 66.67 & 37.00 & 30.00 \\
60 & 573 & & & \\
& R.T. & & & \\
& 373 & 200 & 18.00 & 80.00 \\
& 473 & 80.0 & 30.0 & 68.0 \\
50 & 573 & 60.0 & 11.0 & 48.0 \\
& R.T. & - & - & - \\
& 373 & - & - & - \\
& 473 & 7.41 & 33.00 & 20.00 \\
& 573 & 5.45 & 22.5 & 63 \\
\hline
\end{tabular}

\section{Conclusions:}

1-The sparred pyrolysis method produced polycrystalline $\left(\mathrm{SnO}_{2}\right)_{1-\mathrm{x}}\left(\mathrm{TiO}_{2}: \mathrm{CuO}\right)_{\mathrm{x}}$ thin films with tetragonal structure.

2- The addition of both oxides made the prepared thin films more opaque and hence reduced the transmittance and energy gap and increases the optical constants.
3- Good correlation obtained between the sensitivity and crystal size.

4- The prepared samples useful as high temperature gas sensor.

5-Our project was successfully done as enhancement of sensitivity of the sensing properties of $\mathrm{SnO}_{2}$.

\section{Conflicts of Interest: None.}

\section{References}

1. Qi W, Jang L, Shi S. NanoSnO ${ }_{2}$ Gas Sensors. Curr Nanosci. 2010; 6: 525-538.

2. Oboudi S. Effect of annealing time on the optical constants of $\mathrm{SnO}_{2}$ thin films synthesized by spray pyrolysis technique. J Phys Chem. 2014; 6: 175-182.

3. Low W. The Properties of Sputtered Copper Oxide Thin Film for Sensing Application. MSc Thesis. Malaysia: University Tun Hussein; 2015.

4. Alexander L, Phillip W, Vladimir D. Hybrid $\mathrm{SnO}_{2} / \mathrm{TiO}_{2}$ Nanocomposites for Selective Detection of Ultra-Low Hydrogen Sulfide Concentrations in Complex Backgrounds. Sensors. 2016; 16: 1-15.

5. Jaya B, Pappayee N. Titanium dioxide $\left(\mathrm{TiO}_{2}\right)$ thin film based gas sensors. JCHPS. 2014; 4: 59-61.

6. Panneerdoss I, Jeyakumar S, Jothibas M. Characteristic comparison of $\mathrm{TiO}_{2}$ thin films with an inorganic and organic precursor at different molarities by Spray pyrolysis. Int J Eng Sci. 2014; 4: 15-20.

7. Bari R, Patil S. Studies on spray pyrolised nanostructured $\mathrm{SnO}_{2}$ thin films for $\mathrm{H}_{2}$ gas sensing application. ILCPA. 2014; 36: 125-141.

8. Barbara L, Anna K, Mieczylaw R, Jan Z, Marta G, Katarzyna $\mathrm{M}$, et al. Nanocrystalline $\mathrm{TiO}_{2} / \mathrm{SnO}_{2}$ heterostructures for gas sensing. BJNANO. 2017; 8: 108-122.

9. Philip P, Amrita A, Kirsty G, Alex B, Martin T, Josh $\mathrm{V}$, et al. Practical Use of Metal Oxide Semiconductor Gas Sensors for Measuring Nitrogen Dioxide and Ozone in Urban Environments. Sensors. 2017; 17: 125.

10. Gottling J, Nicol W. Double-Layer Interference in Air-CdS Films. J Opt Soc Am. 1966;56: 1227-1231.

11. Cullity B. Elements of X-Ray Diffraction. $2^{\text {nd }}$ ed.USA: AddisonWesley; 1978.

12. Newman A. Semiconductor Physics and DevicesBasis Principles. $3^{\text {rd }}$ ed.USA: Mcgraw-Hill Companies; 1990.

13. Princea J, Ramamurthy S, Subramanian B, Sanjeeviraja C, Jayachandran M. Spray pyrolysis growth and material properties of $\mathrm{In}_{2} \mathrm{O}_{3}$ films. J Cryst Growth. 2002; 240: 142-151.

14. Joint Committee on Powder Diffraction Standards (JCPDS), International Centre for Diffraction Data, 1997, Card No. 41-1445.

15. Waita S, Aduda M, Mwabora B, Granqvist J, Lindquist C, Niklasson S, et al. Electron Transport and Recombination in Dye Sensitized Solar Cells fabricated from obliquely sputter deposited and thermally annealed $\mathrm{TiO}_{2}$ films. J Electroanal Chem. 2007; 605(2): 151-156. 
16. Wang C, Yin L, Zhang L, Xiang D, Gao R. Metal Oxide Gas Sensors: Sensitivity and Influencing Factors. Sensors. 2010; 19: 2088-2106.

17. Verma $\mathrm{M}$, Gupta V. $\mathrm{SnO}_{2}-\mathrm{CuO}$ nanocomposite thin film sensor for fast detection of $\mathrm{H}_{2} \mathrm{~S}$ gas. J Exp Nanosci. 2013; 8: 326-331.
18. Jin L, Chen W, Zhang H, Xiao G, Yu C, Zhou Q. Characterization of Reduced Graphene Oxide (RGO)Loaded $\mathrm{SnO}_{2}$ Nanocomposite and Applications in $\mathrm{C}_{2} \mathrm{H}_{2}$ Gas Detection. Appl Sci. 2017; 7: 1-15.

\section{تأثير تركيز التثويب على الخواص التركيبية والبصرية والتحسيه للأغثية (الرقيقه 1-x (TiO2: CuO) x}

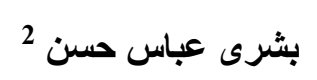

سناره صادق محمود 1

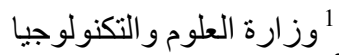

2 قسم الفيزياء، كلية العلوم، جامعة بغداد، يغداد، العراق.

الخلاصة:

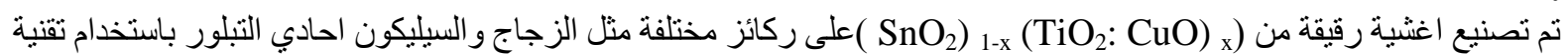

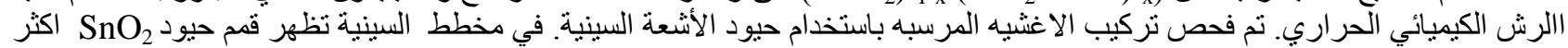
وضوحا في حين لا تظهر قمم

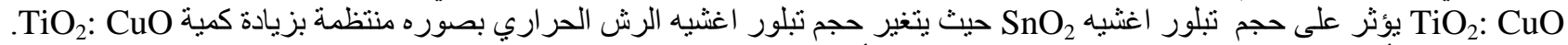

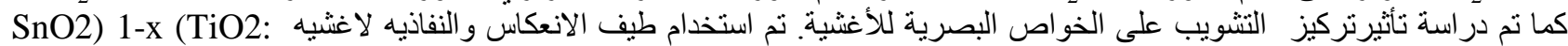

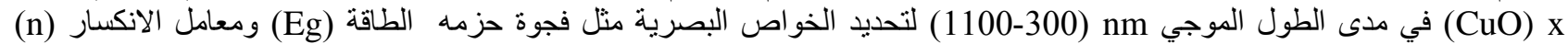

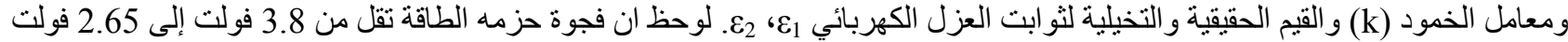

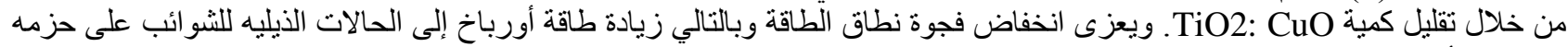

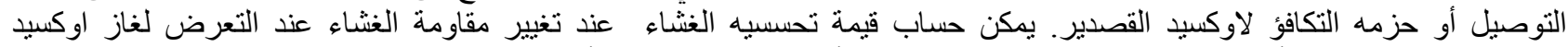
النيتروجين. نظهر النتائج أن اغشيه لأوكيد $\mathrm{SnO}_{2}$ المشوبه لديها حساسية أفضل عند مقارنتها بالأغشية غير المشوبه.

الكلمات المفتاحيه: 